\title{
Agro-Morphological Variability Assessment of Common Bean (Phaseolus vulgaris L.) Genotypes in High Hill Jumla, Nepal
}

\author{
Arjun Chhetri, Anjan Bhatta
}

\author{
Nepal Agricultural Research Council (NARC), Nepal
}

\begin{abstract}
Common bean (Phaseolus vulgaris L.) is the most important leguminous crop widely grown from Terai to high hills of Nepal covering 10,529 hectare land producing $15550 \mathrm{mt}$ with the productivity of $1477 \mathrm{kgha}^{-1}$ and Jumla occupies almost $21 \%$ of the total bean cultivated area of the country. For the experiment, twelve genotypes of common bean were collected from different locations of Nepal. The experiment was conducted at Agricultural Research Station Vijayanagar, Jumla Nepal from July, 2016 to October, 2016 in Randomized Complete Block Design with three replications and twelve treatments. Different agro-morphological characters were observed and wide variability was recorded in growth habit, flower color, seed color, seed shape, seed length $(0.76-1.7 \mathrm{~cm})$, pod color, pod length(9.1-14.3 cm), plant height (57.1-116.5 $\mathrm{cm}$ ), days to flowering (38-52 days) and maturity (74-90 days), number of pods plant ${ }^{-1}$ (9-22 seeds), number of seeds pod $^{-1}$ (4-8 pods), hundred grain weight (18.3-54.7gm) and yield (2339-4164Kg $\left.\mathrm{Ha}^{-1}\right)$. Significant differences were found among genotypes for days to flowering, pod length, no of seeds pod $^{-1}$ and yield hectare ${ }^{-1}$.The coefficients of determination illustrate the positive and significant association of grain yield hectare ${ }^{-1}$ with number of seeds pods $^{-1}$, therefore these traits should be considered for genetic improvement through breeding.
\end{abstract}

Keywords- Common bean, agro-morphological, genotypes, variability, breeding.

\section{INTRODUCTION}

Common bean (Phaseolus vulgaris L.) is the most important leguminous crop widely grown from Terai to high hills of Nepal. It is important cash crop of mid-western development region grown during summer in upland under rain fed condition. It is annual crop, tolerant to drought. The performance of bean is well in drier areas where the climatic condition to cultivate maize is suitable (Alghamdi, 2007). Since, bean is a warm season grain legume, it cannot be grown well under temperature below $20^{\circ} \mathrm{C}$. The optimum mean temperature for common bean is $20-25^{\circ} \mathrm{C}$. High temperature hindrances with seed setting while low temperature has adverse effects on growth (Alghamdi \& Ali, 2004).In Nepal, it covers 10,529 ha land producing $15550 \mathrm{mt}$ with the productivity of $1477 \mathrm{kgha}^{-1}$ (ABPSD, 2015). Only at Jumla, a district of high hill, it occupies almost $21 \%$ of the total cultivated area of the country (DADO Jumla). The crop has more importance in subsistence agro-farming system where it is grown without or with little external input in marginal land. However, farmers today, consider bean as a cash crop and grow a number of landraces with varying morphology (Neupane and Vaidya, 2002).

The primary center of origin and diversity for common beans is considered to be the Americas, where various researches have suggested that most groups are derived from the Andean common bean gene pool (Gepts et al. 1986). However, common beans are widely distributed and very diverse all around the world, whole in Europe and Asia (Blair et al. 2010).

Common bean is consumed in various ways: as split and whole dal, as a dry bean, as green pod vegetable. Bean flour is used for making roti (bread) and dhindo (thick porridge), khichdi (rice and beans cooked together). It is used as a folk medicine for diarrhoea, dropsy, dysentery, diabetes and kidney problems (Duke, 1991). Bean seed is rich in protein contents, fibre, polyphenols, flavonoids, carotenoids, saponins, oligosaccharides, condensed tannins, lectins, trypsin inhibitors and phytic acid which are considered to be the most important phytochemical responsible for antioxidant biological activities and preventive against cardiovascular or chronic degenerative(Camacho et al. 2006). Also it is source of essential vitamins (A, $B_{12}$ and C), minerals and dietary fiber, which make it an excellent component of the human nutrition (Filgueira 2013). 
Various studies of common bean in high hills of Nepal particularly in Jumla district have indicated that it contains the greatest genetic diversity of Phaseolus vulgaris. Jumla, which is famous as a potential area of bean production is deprived of most of the activities regarding the characterization of the beans. The maintenance of this diversity is fundamental to develop and support breeding programs and enhance productivity. Morphological and agronomic traits of the plant are preferred for the primary characterization of the genotypes as it is being cheaper and easier to assess. Several characters are used to characterize genetic resources, particularly morphological and agronomic (Singh 2001). The present work is aimed to assess the genetic divergence among the bean genotypes evaluated and the extent of phenotypic and genetic variability with respect to agro-morphological traits.

\section{MATERIALS AND METHODS}

The experiment was conducted in the field, at the Agricultural Research Station Vijayanagar, Jumla Nepal, geographically located at $29^{\circ} 17^{\prime} \mathrm{N}$ latitude and $82^{\circ} 1^{\prime} \mathrm{E}$ longitude with an elevation of $2290 \mathrm{~m}$ amsl. Climatic condition in Jumla ranges from cool summer to freezing winter with low humidity and low rainfall.

Twelve genotypes of common bean were collected for the experiment from different locations of Nepal. PB lines were introduced in Jumla from National Grain Legume Research Program Khajura, Nepalgunj which have been cultivated by farmers of Jumla and KBL lines were collected from the
Jumla which have been cultivated in Karnali region since very long time.

The experiment was conducted from July, 2016 to October, 2016 in Randomized Complete Block Design with three replications and twelve treatments. The plot size for each treatment was six square meter with row to row distance 50 $\mathrm{cm}$ and plant to plant distance of $10 \mathrm{~cm}$ adjusting four rows each measuring $3 \mathrm{~m}$ length. The seed was sown on 9 July, 2016. The seed rate and fertilizer dose used was $120 \mathrm{~kg} / \mathrm{ha}$ and 100:60:40 NPK kg/ha respectively. Nitrogen was provided in two splits, half as basal dose and next half was top dressed at vegetative growth stage just after first weeding (one month after sowing). Data were recorded for agro-morphic characters like days to $50 \%$ flowering (DF), Days to $75 \%$ maturity (DM), Plant height (PH), pod length (PL), number of pods plant ${ }^{-1}$ (NOPP), number of seeds pod ${ }^{1}$ (NOSP), seed size, 100 seed weight and grain yield. The morphological characters were flower color, growth habit, pod color, seed shape and seed color (IBPGR, 1982).

\section{Statistical Analysis}

The data recorded were entered in microsoft excel 2016 and analysis was done in R Studio 3.1.1. Duncan Multiple Range Test (DMRT) was done in 5\% level of significance for mean comparison. Correlation and regression analysis were done using microsoft excel. T test and cluster analysis was performed using agricolae package and h-clust respectively. Data was normalized before calculation of Euclidean distance (Wiley, 2014).

\section{RESULTS AND DISCUSSIONS}

\begin{tabular}{|l|l|l|l|l|l|l|}
\hline \multicolumn{7}{|c|}{ Table.1: Agro-morphological traits of 12 genotypes of common bean evaluated at Jumla, Nepal. } \\
\hline $\begin{array}{l}\text { Genotyp } \\
\text { e }\end{array}$ & $\begin{array}{l}\text { Growth } \\
\text { Habit }\end{array}$ & Flower Color & Seed color & Pod Color & $\begin{array}{l}\text { Seed } \\
\text { Shape }\end{array}$ & $\begin{array}{l}\text { Seed } \\
\text { Length(cm) }\end{array}$ \\
\hline PB0001 & Bushy & Light pink to white & $\begin{array}{l}\text { Dark red with white } \\
\text { streaks }\end{array}$ & Green & Kidney & 1.45 \\
\hline PB0002 & Trailing & Dark Pink & $\begin{array}{l}\text { Creamy white with } \\
\text { purple streaks }\end{array}$ & $\begin{array}{l}\text { Green with dark } \\
\text { purple streaks }\end{array}$ & Elongated & 1.39 \\
\hline PB0048 & Trailing & $\begin{array}{l}\text { Very light pink to } \\
\text { white }\end{array}$ & Dark red & Green & Elongated & 1.70 \\
\hline KBL-1 & Trailing & Dark Pink & Black & Green & Elongated & 1.09 \\
\hline KBL-2 & Trailing & White & Dark Red & Reddish Green & Elongated & 1.09 \\
\hline KBL-3 & Trailing & Very dark pink & $\begin{array}{l}\text { Dark purple with white } \\
\text { streaks }\end{array}$ & Green & Elongated & 1.25 \\
\hline KBL-4 & Trailing & Dark Pink & $\begin{array}{l}\text { Creamy to very light } \\
\text { brown }\end{array}$ & Green & Flattened \\
elongated & 1.08 \\
\hline KBL-5 & Bushy & Pink & Light brown & Green & Elongated & 1.36 \\
\hline KBL-6 & Trailing & White & White & Green & Elongated & 0.76 \\
\hline KBL-7 & Trailing & Whitish Pink to dark & Creamy to very light & Green & Oval & 1.06 \\
\hline
\end{tabular}




\begin{tabular}{|l|l|l|l|l|l|l|}
\hline & & pink & brown & & \\
\hline KBL-8 & Bushy & $\begin{array}{l}\text { Very Light Pink to } \\
\text { white }\end{array}$ & $\begin{array}{l}\text { White with dark red } \\
\text { streaks }\end{array}$ & Green & Kidney & 1.52 \\
\hline KBL-9 & Trailing & Dark Pink & Light to dark grey & Green & Elongated & 1.04 \\
\hline
\end{tabular}

Three genotypes PB0001, KBL-5 and KBL-8 are bushy in nature whereas all others are trailing type. The flower color shows variations from white, light pink to very dark pink and the seed color varies widely among genotypes. The color of pods at maturity ranges from yellow, purple stripe on white to caramine red. The seed shape of two genotypes
PB0001 and KBL-8 were kidney shaped, KBL-7 was oval shaped, KBL-4 was flattened elongated and all other genotypes possessed elongated seed. The seed length ranges from 0.76 to $1.7 \mathrm{~cm}$ in which PB0048 possessed highest seed length $1.70 \mathrm{~cm}$ and KBL-6 showed lowest seed length, $0.76 \mathrm{~cm}$ (Table 1).

\begin{tabular}{|c|c|c|c|c|c|c|c|c|c|}
\hline S.N & Genotypes & FD & MD & $\mathbf{P H}$ & NOPP & PL & NOSP & HGW & YLD \\
\hline 1 & PB0001 & 47 & 87 & 57.7 & 13 & 9.5 & 4 & 43.3 & $3691^{\mathrm{ABC}}$ \\
\hline 2 & PB0002 & 51 & 84 & 109.1 & 16 & 10.7 & 6 & 36 & $3610^{\mathrm{ABC}}$ \\
\hline 3 & PB0048 & 45 & 84 & 110.6 & 18 & 10.7 & 4 & 47.3 & $3222^{\mathrm{ABCD}}$ \\
\hline 4 & KBL-1 & 49 & 85 & 116.5 & 20 & 9.9 & 7 & 23 & $3683^{\mathrm{ABC}}$ \\
\hline 5 & KBL-2 & 46 & 84 & 103.1 & 16 & 9.7 & 8 & 24.3 & $4164^{\mathrm{A}}$ \\
\hline 6 & KBL-3 & 52 & 90 & 100.5 & 15 & 10.4 & 6 & 29 & $3538^{\mathrm{ABC}}$ \\
\hline 7 & KBL-4 & 50 & 90 & 82.7 & 17 & 10.5 & 6 & 26.3 & $3796^{\mathrm{AB}}$ \\
\hline 8 & KBL-5 & 38 & 74 & 62.5 & 15 & 14.3 & 6 & 31 & $2620^{\mathrm{BCD}}$ \\
\hline 9 & KBL-6 & 47 & 84 & 78.6 & 22 & 9.1 & 6 & 18.3 & $3779^{\mathrm{AB}}$ \\
\hline 10 & KBL-7 & 45 & 88 & 97.5 & 12 & 10.8 & 7 & 39 & $2339^{\mathrm{D}}$ \\
\hline 11 & KBL-8 & 38 & 79 & 57.1 & 9 & 12.3 & 5 & 54.7 & $2517^{\mathrm{CD}}$ \\
\hline 12 & KBL-9 & 45 & 87 & 90.3 & 17 & 11.3 & 7 & 24.3 & $3278^{\mathrm{ABCD}}$ \\
\hline \multicolumn{2}{|r|}{$\mathrm{CV}$} & 9.03 & 5.45 & 30.4 & 25.89 & 13.04 & 16.14 & 34.59 & 21.14 \\
\hline \multicolumn{2}{|r|}{ LSD } & 6.92 & - & - & - & 2.33 & 1.58 & - & 1177.85 \\
\hline \multicolumn{2}{|r|}{ F-test } & $* *$ & NS & NS & NS & $*$ & $*$ & NS & $*$ \\
\hline
\end{tabular}

Note: SN-serial number, FD-days to $50 \%$ flowering,MDdays to $75 \%$ maturity, PH-plant height in $\mathrm{cm}$, NOPPnumber of pods plant ${ }^{-1}$, PL-pods length in $\mathrm{cm}$, NOSPnumber of seeds pod $^{-1}$, HGW-hundred grain weight in gram, YLD-Yield $\mathrm{kgha}^{-1}, \mathrm{CV}$ - coefficient of variation,
LSD-least significant difference. Means followed by the same letters in a column are not significantly different by DMRT at 5\% level of significance, NS-non significant.

Regression Analysis 


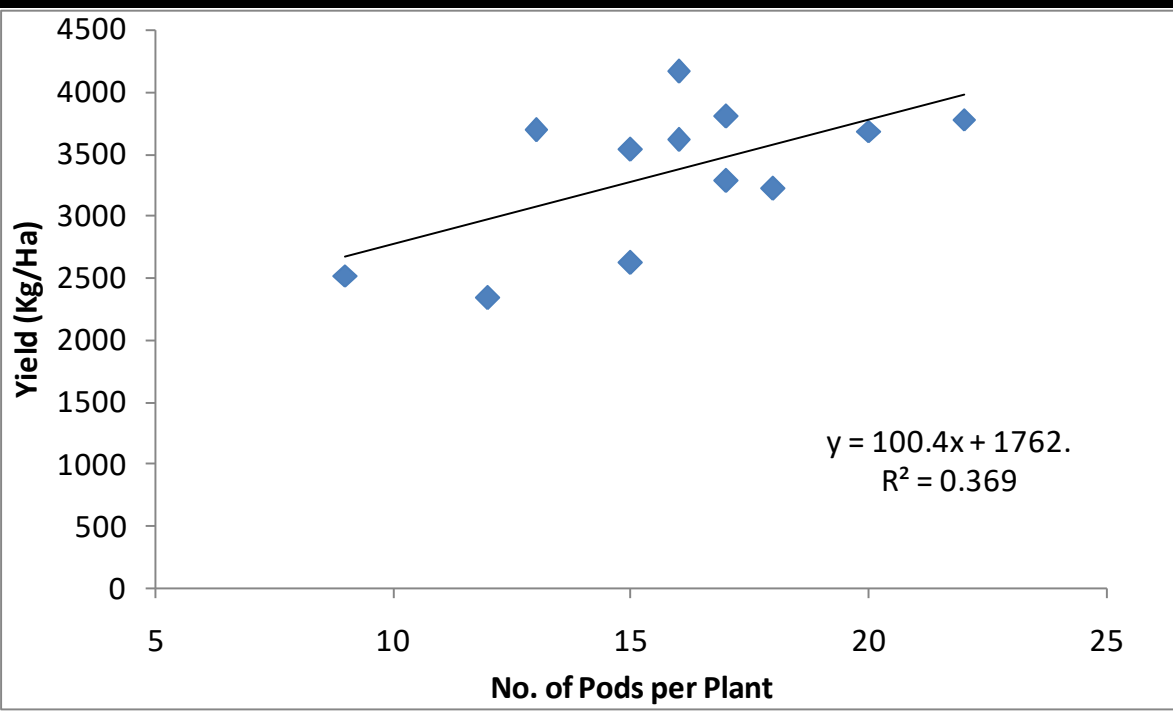

Fig.1: Linear Relationship Between No. of Pods Plant ${ }^{-1}$ and Yield $\left(\mathrm{KgHa}^{-1}\right)$ of Bean Genotypes at Jumla, Nepal.

There is a positive linear relationship between No. of Pods Plant $^{-1}$ and Yield $\left(\mathrm{KgHa}^{-1}\right)$. According to linear regression equation, with unit increased in No. of Pods Plant ${ }^{-1}$, Yield would have been increased by 100.4 times. According to coefficient of determination, about $36.90 \%$ variation in yield was due to No. of Pods Plant ${ }^{-1}$ and remaining portion due to other variables as shown in Figure 1.

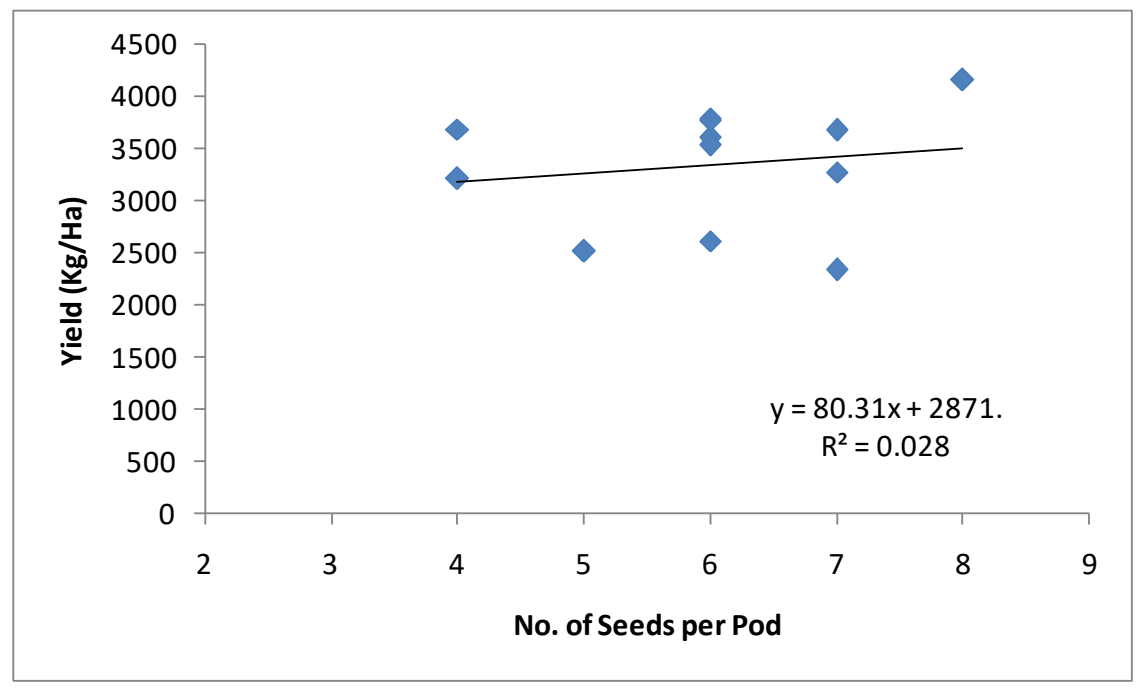

Fig.2: Linear Relationship between No. of Seeds pod $^{-1}$ and Yield $\left(\mathrm{KgHa}^{-1}\right)$ of Bean Genotypes at Jumla, Nepal.

The positive and significant $(\mathrm{P}<0.05)$ linear relationship between No. of Seeds pod ${ }^{-1}$ and Yield $\left(\mathrm{KgHa}^{-1}\right)$ as shown in Figure 2, showed that with unit increased in No. of Seeds pod $^{-1}$ increased in yield by 80.31 times. According to the coefficient of determination about $2.80 \% \quad\left(\mathrm{R}^{2}=0.028\right)$ variation in yield was due to No. of Seeds $\operatorname{pod}^{-1}$ and remaining portion due to other variables. 


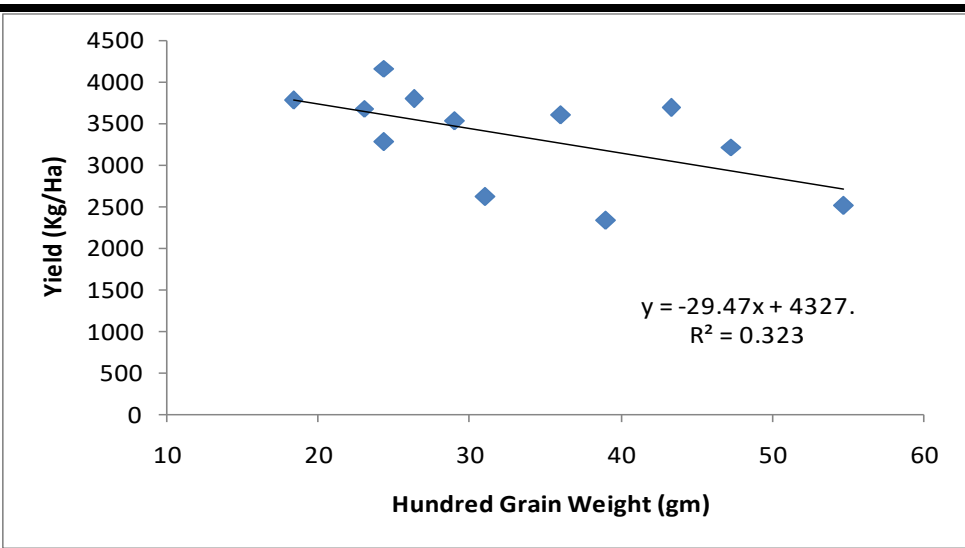

Fig.3: Linear Relationship between Hundred Grain Weight (gm) and Yield $\left(\mathrm{KgHa}^{-1}\right)$ of Bean Genotypes at Jumla, Nepal.

There is a negative linear relationship between hundred grain weight $(\mathrm{gm})$ and Yield $\left(\mathrm{KgHa}^{-1}\right)$. The contribution of hundred grain weight to the yield was approximately
$32.30 \%\left(\mathrm{R}^{2}=0.323\right)$ and remaining portion might be due to other variables as shown in Figure 3.

\section{Cluster Dendrogram}

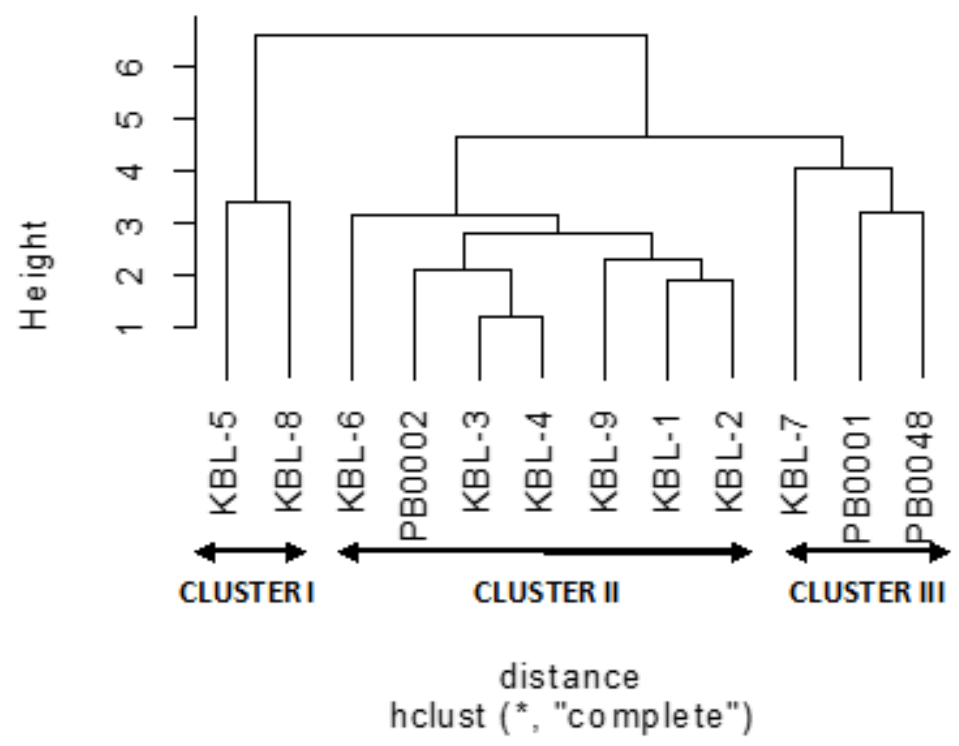

Fig.4: Dendrogram showing clustering pattern of 12 common bean genotypes based on Euclidean distance values obtained from agro-morphological data.

The germplasm used in this experiment were grouped in cluster I, II and III in (Figure 4) which holds 2, 7 and 3 genotypes respectively. The mean value of various traits for each character showed that genotypes with minimum days to flowering, minimum days to maturity, maximum pod length and minimum yield hectare ${ }^{-1}$ were found in cluster I. Likewise, genotypes of cluster II constitute maximum days to maturity, maximum plant height, maximum no. of pods plant $^{-1}$, minimum hundred grain weight and maximum yield hectare $^{-1}$. Genotypes with similar pod length and similar days to flowering and days to maturity were kept in cluster III.

\section{CONCLUSION}

Genotypes on intra cluster showed similar agromorphological traits whereas inter clusters' genotypes showed higher agro-morphic diversity, mainly for days to flowering, pod length, no of seeds pod ${ }^{-1}$ and yield hectare ${ }^{-1}$. 
Therefore, for further improvement, effective phenotypic selection can be done from these diversified genotypes however, it is now essential to undertake more research work on characterization of common bean from Jumla, Nepal.

\section{ACKNOWLEDGEMENT}

The authors are highly indebted to Nepal Agricultural Research Council, Agricultural Research Station Vijayanagar, Jumla, Nepal for the conduction of research and its funding. Their gratitude extends to all staffs of ARS Vijayanagar, Jumla, Nepal.

\section{REFERENCES}

[1] ABPSD (2015) Statistical Information of Nepalese agriculture, 2015. Ministry of Agricultural Development, Kathmandu, Nepal.

[2] Alghamdi, S. S., Kh and A. Ali. 2004. Performance of several newly bred faba bean lines. Egypt. J. Plant Breed., 8: 189-200.

[3] Alghamdi, S. S. 2007. Genetic behavior of some selected faba bean genotypes. African Crop Sci.Conference proceedings. African Crop Science Society. El-Minia, Egypt, 8: 709-714.

[4] Blair, M. W. et al. Extensive diversity and intergenepool introgression in a world-wide collection of indeterminatesnap beans accessions. Theoretical and Applied Genetics, v. 120, n. 7, p. 1381-1391, 2010.

[5] Duke, J. A. 1981. Handbook of Legumes of World Economic Importance. USDA, Bellsville, Maryland, New York and London.

[6] Filgueira, F. A. R. Novo manual de olericultura:agrotecnologia moderna na produção e comercialização de hortaliças. 3. ed. Viçosa: UFV, 2013.

[7] Gepts, P. et al. Phaseolin-protein variability in wild forms and landraces of the common beans (Phaseolus vulgaris): evidence for multiple center of domestication. Economic Botany, v. 40, n. 4, p. 451456, 1986.

[8] Krishi Bikash Karyakram Tatha Tathyanka Ek Jhalak 2071/072, District Agriculture Development Office (DADO) Jumla, 2015.

[9] Neupane, R. K. and Vaidya, M. L. 2002. Proceedings of the first stakeholders' meeting on development of improved production technology of Phaseolus beans to the hills of mid western Nepal, 22 June 2002 ARS, Jumla. NGLRP Rampur.
[10] Singh SP (2001) Broadening the genetic base of common bean cultivars: a review. Crop Science 41: 1659-1675.

[11] Wiley J. (2014) Wiley StatsRef: Statistical Reference online: onlinelibrary.wiley.com. 